Доброва Н.В., Осипова М. М., Сментина Н.В.

\title{
ЕФЕКТИВНІСТЬ ФУНКЦІОНУВАННЯ ПІДПРИЄМСТВ МІСЬКОГО ЕЛЕКТРОТРАНСПОРТУ В КОНТЕКСТІ ОНОВЛЕННЯ ТА МОДЕРНІЗАЦІЇ ТЕХНІЧНОӤ БАЗИ
}

\begin{abstract}
Наведені фактори, які обумовлюють низьку якість послуг міського електротранспорту. Окреслені вектори відродження технічного потенціалу електротранспортних підприємств міста. Зосереджена увага на доцільності інновачійного оновлення та модернізаџії технічної бази електротранспортних підприємств міста. Визначені переваги інновачійного оновлення рухомого складу підприємств міського електротранспорту на прикладі одного з передових електротранспортних підприємств півдня краӥни. Проаналізовані фактори, щзо впливають на розмір економічного ефекту від оновлення та модернізації вагонного парку підприємства.
\end{abstract}

Ключові слова: електротранспорт, рухомий склад, технічний потенціал, модернізація, ефективність.

Постановка проблеми. Важливою складовою міського господарства $€$ міський електричний транспорт, призначений для перевезення громадян трамваями, тролейбусами, поїздами метрополітену на маршрутах (лініях) відповідно до вимог життєзабезпечення населених пунктів. Міський електротранспорт займає провідні позиції на ринку транспортних послуг України (функціонує у 54 містах, забезпечуючи більше половини внутрішньоміських пасажироперевезень), в першу чергу, з огляду на вагоме соціально-економічне значення у системі міських пасажирських перевезень, залишаючись найбільш економічним, екологічним і доступним видом транспорту. Разом з тим, сьогодення висуває до підприємств міського електротранспорту більш жорсткі вимоги щодо якості послуг 3 перевезення пасажирів. Так, більш вимогливі показники стосуються комфортності користування цим видом транспорту, регулярності сполучення, безпечності поїдки, інформативності й доступності тарифів, врахування потреб людей 3 обмеженими можливостями (інвалідів 3 ураженнями органів зору, слуху, опорнорухового апарату та інших маломобільних груп населення) та ін. аспектів якості послуг 3

(C) Доброва Наталя Василівна, к.е.н., доцент, доцент кафедри економіки та планування бізнесу, Одеський національний економічний університет, м. Одеса, тел.: +380677382717 ,

dobrovanataly1963@gmail.com

Осипова Марія Михайлівна, к.е.н., доцент, доцент кафедри економіки та планування бізнесу, Одеський національний економічний університет, м. Одеса, тел..: +380674849679, e-mail: maria55557@ rambler.ru

Сментина Наталія Валентинівна, д.е.н., доцент, професор кафедри економіки та планування бізнесу, Одеський національний економічний університет, м. Одеса, тел.: +380677614615, (048)723-32-56, e-mail: smentn@ukr.net перевезень пасажирів у зв'язку 3 обраним Україною курсом на євроінтеграцію.

Однак останніми роками діяльність підприємств міського електротранспорту характеризується низкою негативних факторів (зокрема погіршенням стану рухомого складу та якості транспортного обслуговування населення, зниженням рівня безпеки руху, зменшенням обсягів пасажироперевезень, скороченням експлуатаційної довжини тролейбусних та трамвайних ліній та ін.), що у кінцевому підсумку позначається на ефективності функціонування підприємств міського електротранспорту, зростанні рівня незадоволеного попиту населення послугами, що надаються. Тому, організація ефективного управління міським електротранспортом і пошук шляхів удосконалення діяльності підприємств міського електротранспорту - пріоритетні завдання економічного розвитку держави. При цьому в контексті сучасних євроінтеграційних процесів важливим для України є досвід країн Європейського Союзу, які мають значні досягнення в організації роботи підприємств міського електротранспорту.

Аналіз останніх досліджень та публікацій. Проблеми функціонування підприємств міського електротранспорту висвітлені у працях таких українських вчених-економістів, як Амоша О. I. [1], Філіппова О. С. [2], Омельянович О. Р., Прима Ю. І. [3], Дивінець О. Л. [4], Чеканова Л. Г., Палант О. Ю., Кушнір Т. Б. [5] та ін. Особливу увагу дослідники приділяють пошуку альтернативних сучасним напрямів реформування діючої системи пасажирських перевезень міським електротранспортом. Водночас, визнаючи вагомий внесок науковців у вирішення стратегічного завдання економічного та соціального спрямування - обгрунтування заходів, запровадження яких сприятиме 
ефективному розвитку галузі, у сучасній літературі недостатньо розробленими лишається проблема ефективності функціонування підприємств міського електротранспорту у контексті визначення економічного ефекту від відродження їх технічного потенціалу.

Формулювання цілей статті. Мета статті оцінити можливості підвищення ефективності господарської діяльності підприємств міського електротранспорту через визначення розміру економічного ефекту від інноваційного оновлення їх основних засобів.

Опис основних результатів дослідження. Системоутворюючу роль у господарській діяльності підприємств міського електротранспорту відіграє їх технічний потенціал. Сьогодні розвиток міського електротранспорту стримується значним фізичним та моральним зносом основних засобів. Трамвайні вагони та тролейбуси, що перебувають на балансі міських електротранспортних підприємств, уже відпрацювали свій нормативних строк експлуатації або ж потребують капітального ремонту. Зношеність рухомого складу по трамвайних вагонах складає $93,6 \%$, по тролейбусах $-66,7 \%$ [6]. Незадовільний технічний стан рухомого складу електротранспортних підприємств, його віковий склад та інші параметри суттєво знижають якість послуг 3 перевезень пасажирів.

Для підтримання у технічно справному стані фізично зношеного та морально застарілого рухомого складу витрачаються значні кошти, але результат малоефективний. Зношений рухомий склад часто виходить 3 ладу та потребує проведення додаткових, непланових ремонтів. Подальша експлуатація такого застарілого рухомого складу веде до неминучого збільшення експлуатаційних витрат електротранспортних підприємств (зокрема витрат на спожиту електроенергію, витрат на ремонт тощо), а також до збільшення рівня його аварійності.

Можливість придбання нових одиниць рухомого складу значно ускладнено нестачею коштів як у підприємств галузі, так і в бюджетах всіх рівнів внаслідок відсутності закріпленої статті фінансування, тому постає питання пошуку альтернативних джерел фінансування. Такі можливості, наприклад, відкриваються завдяки програмі Європейського банку реконструкції та розвитку (далі - СБРР). Так, ЄБРР у 2015 році затвердив фінансову програму на суму 100 млн євро для вдосконалення громадського транспорту в українських містах, а м. Одеса стало першим містом, якому виділено фінансування за цією програмою [7]. У 2015 році в Одеській міській раді підписано договір про виділення комунальному підприємству (далі -
КП) «Одесміськелектротрас» кредиту для придбання 48 нових тролейбусів. Це дозволить замінити майже половину морально і фізично застарілого міського парку тролейбусів на новий, екологічно чистий та економічний рухомий склад. СБРР надав підприємству 8 млн євро терміном на дванадцять років.

Загалом подолання кризового стану міського електричного транспорту та забезпечення населення якісними транспортними послугами можливе шляхом реалізації інноваційних проектів, спрямованих на техніко-технологічне переоснащення підприємств галузі. Інноваційне оновлення основних засобів міського електротранспорту, як відмічає у своїх роботах К. В. Гнедіна, слід розглядати як впровадження технічних інновацій 3 метою вдосконалення техніко-технологічної бази підприємств, що призводить до підвищення якості транспортних послуг [8, с. 94].

Разом 3 тим, у сучасних умовах відтворення електротранспортних мереж це вкрай необхідна, але недостатня умова відродження технічного потенціалу електротранспортних підприємств. Вимогою сучасності $є$ створення швидкісних монорельсових мереж 3 високою провізною здатністю. Дієвим методом забезпечення стійкого розвитку електротранспортних підприємств міст може стати створення інфраструктурних об'єктів, що сполучають різні види транспорту. Так, одним із інноваційних напрямів розвитку міського пасажирського транспорту $\epsilon$ створення принципово нового елемента міської транспортної інфраструктури транспортно-пересадкових вузлів у місцях взаємодії різних видів транспорту. Такі інфраструктурні об'єкти забезпечують впорядковану посадку i висадку пасажирів, оптимальну організацію процесу пересадки та включають в свій склад різні сервісні об'єкти обслуговування пасажирів.

Дієвим методом підвищення доходів електротранспортних підприємств може стати удосконалення тарифної політики та механізмів оплати за пасажирські перевезення. Існуюча специфіка ціноутворення визначає встановлення єдиного тарифу на проїзд в міському електротранспорті в межах одного міста, не враховуючи протяжності маршрутів. У той самий час досвід країн Європи вказує на ефективність та необхідність застосування диференційованих тарифів залежно від дальності або ж тривалості поїздки. Разом 3 тим, для створення об'єктивної основи для розрахунку диференційних тарифів необхідною $є$ розробка методики визначення базового тарифу на перевезення пасажирів i подальша його 
диференціація залежно від дальності поїздки та, наприклад, мінімальної кількості зупинок, комфортності салону і т.п.

Варто визнати, що в державі розуміють гостроту проблеми галузі та вдаються до визначення стратегічних напрямів щодо i розв'язання. Свідченням цьому $\epsilon$, наприклад, розроблена Державна цільова програму розвитку міського електротранспорту, яка визначає шляхи i способи забезпечення належного рівня перевезень пасажирів міським електротранспортом. Одним із таких шляхів $є$ саме оновлення та модернізація технічного потенціалу електротранспортних підприємств, вигоди та розмір економічного ефекту від яких розглянемо на прикладі КП «Одесміськелектротранс», яке за результатами роботи посідає третє місце серед підприємств міського електротранспорту України [9].

В першу чергу, інноваційне оновлення технічної бази КП «Одесміськелектротранс» можливе за рахунок придбання абсолютно нового рухомого складу, що дозволить: підвищити привабливість міського електротранспорту; покращити якість пасажирських перевезень; здійснювати перевезення пасажирів з обмеженими фізичними можливостями; забезпечити місто комфортним та доступним транспортом; а також поліпшить низку економічних показників господарської діяльності комунального підприємства (наприклад, збільшить обсяг пасажирських перевезень, знизить витрати на технічне обслуговування, витрати електроенергії, тощо).

Станом на 01.01.2016 р. парк рухомого складу КП «Одесміськелектротранс» становив 252 одиниці трамваїв (із них 228 одиниць пасажирських) і 174 одиниць тролейбусів (170 одиниць - пасажирських, з них за маркою: ЗиУ682 - 100 одиниць; ЮМЗ-Т1 -16 одиниць; ЮМ3 Т-2 -25 одиниць; Тролза - 16 одиниць; Шкода (14TR i 21TR) - 13 одиниць). Сьогодні в КП експлуатуються 217 одиниць пасажирських трамваїв та 151 одиниця тролейбусів, 95,2 \% та $88,8 \% \quad 3$ яких відповідно відпрацювали нормативний термін експлуатації. Зважаючи на вікову структуру тролейбусного парку, умовний інноваційний проект оновлення рухомого складу тролейбусів, який розглядається у якості прикладу, передбачає оновлення найстаріших тролейбусів марки ЗиУ-682, які знаходяться в експлуатації з 1970 по 1972 роки, тобто їх фактичний вік становить понад 44 роки [10]. Проект передбачає придбання 48 нових низькопідлогових тролейбусів «Богдан».

Серед основних переваг нових тролейбусів варто виділити такі:
1. Сучасні нові тролейбуси забезпечені енергозберігаючими безреостатними системами керування тяговими двигунами, які дають можливість економії до $36 \%$ електричної енергії на забезпечення руху тролейбусів.

2. Придбання нових тролейбусів дозволить ліквідувати додаткові витрати на матеріали та заробітну плату за рахунок зменшення поточних та капітальних ремонтних робіт, а також зменшення рівня аварійності транспорту.

3. Нові тролейбуси дадуть можливість зменшити час на посадку і висадку пасажирів за рахунок низького рівня підлоги.

4. За рахунок високих динамічних характеристик стане можливим збільшення експлуатаційної швидкості тролейбусів на 20 $25 \%$.

5. Збільшення швидкості руху дозволить скоротити кількість рухомого складу, необхідного для забезпечення пасажирських перевезень, зменшити загальні витрати на його утримання, заробітну плату водіїв і кондукторів.

6. Позитивний вплив матиме реалізація проекту на соціальні аспекти обслуговування пасажирів та мешканців міста, про що неодноразово відмічають науковці [11, с. 149], а саме:

- підвищиться рівень комфортності перевезення пасажирів;

- низький рівень підлоги нових тролейбусів зробить доступними їх для осіб з обмеженими фізичними можливостями;

- за рахунок екологічної чистоти тролейбусів і значно нижчого рівня шкідливих викидів в атмосферу порівняно 3 автобусами поліпшиться стан екології в місті;

- за рахунок високої провізної спроможності, зменшиться навантаження на пропускну спроможність вулиць і поліпшиться стан організації вуличного руху в місті.

Інноваційне оновлення рухомого складу тролейбусів варто проводити 3 одночасною утилізацією старих тролейбусів, шляхом їх здачі на металобрухт. За даними КП «Одесміськелектротранс» утилізація одного тролейбусу в середньому приносить дохід у pозмірі 30 тис. грн. Таким чином, очікуваний дохід підприємства від утилізації 48 тролейбусних машин становитиме 1440 тис. грн.

Що стосується вибору моделей нових тролейбусів, то в Україні наразі створена власна виробнича база з виготовлення рухомого складу міського електротранспорту. Виробництво тролейбусів освоєно: Луцьким автомобільним заводом (корпорація «Богдан»), Львівським заводом комунального транспорту (ЛАЗ). Вітчизняні виробники здатні забезпечити потребу 
підприємств міського електротранспорту у рухомому складі, який за показниками енергоспоживання, надійності і комфортності не поступається аналогам у розвинутих європейських країнах та СНД [12, с. 173].

Загалом річний економічний ефект від введення в експлуатацію 48 нових тролейбусів буде досягнуто за рахунок таких факторів:

1) зменшення витрат на заробітну плату працівникам ремонтної служби підприємства (фактична частка трудових витрат, яка припадає на зарплату на проведення середніх та капітальних ремонтів в загальній сумі зарплати ремонтних працівників на підприємстві становила в 2016 році $-50 \%$ );
2) зменшення витрат на матеріали та запчастини для ремонту тролейбусів (частка вартості матеріалів та запчастин, використаних на проведення середніх та капітальних ремонтів, у загальній сумі витрат на матеріали та капітальні ремонти в 2016 році становила 80\%);

3) зменшення витрат на електроенергію для руху тролейбусів за рахунок безреостатних систем керування тяговими двигунами $-36 \%$.

Розрахунок річного економічного ефекту від оновлення рухомого складу тролейбусів КП «Одесміськелектротранс», 3 урахуванням наведених вище факторів, представлено у таблиці 1.

Розрахунок економічного ефекту КП «Одесміськелектротранс» від оновлення парку тролейбусних вагонів*

\begin{tabular}{|l|c|c|c|}
\hline \multicolumn{1}{|c|}{ Статті витрат } & $\begin{array}{c}\text { Витрати на утримання } \\
\text { всього парку } \\
\text { тролейбусів, } \\
\text { тис. грн. [10] }\end{array}$ & $\begin{array}{c}\text { Економія на } \\
\text { утриманні нових } \\
\text { тролейбусів, } \\
\text { тис. грн }\end{array}$ & $\begin{array}{c}\text { Витрати на утримання } \\
\text { парку тролейбусів після } \\
\text { оновлення, } \\
\text { тис. грн }\end{array}$ \\
\hline $\begin{array}{l}\text { Заробітна плата ремонтного } \\
\text { персоналу з ССВ }\end{array}$ & 2593,2 & 15775,3 \\
\hline $\begin{array}{l}\text { Технічне обслуговування, } \\
\text { матеріали та запчастини на } \\
\text { ремонт }\end{array}$ & 718368,5 & 405,12 & 6765,48 \\
\hline $\begin{array}{l}\text { Разом витрати на експлуатацію } \\
\text { по Депо }\end{array}$ & 25539,1 & 2998,32 & 22540,78 \\
\hline $\begin{array}{l}\text { Витрати на електроенергію на } \\
\text { рух }\end{array}$ & 13316,1 & 2406,24 & 10909,86 \\
\hline $\begin{array}{l}\text { Разом витрати на перевезення } \\
\text { пасажирів }\end{array}$ & 38855,2 & 5404,56 & 33450,64 \\
\hline
\end{tabular}

* Авторські розрахунки

3 даних таблиці 1 видно, що річний економічний ефект від введення в експлуатацію нових тролейбусів складе 5404,56 тис. грн. Разом з цим, як зазначалося вище, додатковий дохід від утилізації старих тролейбусів складе 1440,00 тис. грн. Таким чином, загальна сума річного економічного ефекту комунального підприємства становитиме 6844,56 тис. грн. Враховуючи поточні ціни на тролейбуси, сумарні витрати за проектом на оновлення тролейбусів становитимуть 254,4 млн грн.

Оскільки даний проект носить соціальний характер, а одержувачем коштів є підприємство комунальної форми власності, то фінансування реалізації подібних проектів в інших містах країни можна здійснювати за рахунок залучення під державні (місцеві) гарантії коштів шляхом оформлення кредиту. Джерелом фінансування оновлення рухомого складу тролейбусів можуть бути кредити, залучені під місцеві гарантії. При цьому можливі два варіанти отримання кредитних коштів під місцеві гарантії: кредити українських банків чи кредити міжнародних фінансових установ. Альтернативним джерелом фінансування можуть виступити кредитні кошти, надані Європейським банком реконструкцій i розвитку, про що йшлося вище, які надаються під міські гарантії на реалізацію найважливіших заходів 3 поліпшення інфраструктури громадського транспорту. Відповідні проекти приділяють першочергову увагу оновленню рухомого складу та відповідному підвищенню ефективності. При цьому ЄБРР укладатиме кредитний договір 3 транспортним підприємством і договір гарантії та підтримки проекту 3 відповідним містом. Кожний кредит супроводжуватиметься гарантією відповідного міста. Відсоткова ставка за користування залученими коштами за вимогами ЄБРР складається зі: ставки Euribor (3,2\%) + маржа (5 7 \% на рік, з можливістю зниження в залежності від кредитного рейтингу міста та досягнення позичальником показників тарифів та фінансових коефіцієнтів, що задовольняють банк, але не нижче 4,00\%). Таким чином, середня 
відсоткова ставка ЄБРР становитиме близько $11 \%$ - річних [13].

Альтернативним варіантом до закупівлі абсолютно нового парку електротранспортних засобів є оновлення рухомого складу, шляхом проведення модернізації. Розглянемо цей варіант для оновлення парку трамваїв 3 наступних причин. Щодня на трамвайні маршрути міста Одеси виходить близько 160 трамваїв, ще 60 знаходяться в резерві. Наразі рухомий склад трамваїв перебуває у не найкращому стані, так, оновлення потребують близько 200 одиниць трамваїв, проте значною перешкодою у цьому $\epsilon$ досить висока вартість трамваїв. Так, у середньому ціна нового трамваю стартує від 14 млн грн. У зв'язку з цим, починаючи з 2014 року на КП «Одесміськелектротранс» успішно розробляються заходи 3 проведення модернізації старих трамвайних вагонів.

Наразі КП «Одесміськелектротранс» - перше комунальне підприємство в Україні, на якому створені технічні умови для капітального ремонту $з$ переобладнанням частково трамваїв 3 низькою підлогою. У червні 2016 року завершено процедуру отримання та реєстрації технічних умов, що дозволяють підприємству самостійно виробляти частково трамвайні вагони 3 низькою підлогою за принципом капітального ремонту та реконструкцією. Загальна ідея модернізації трамвайного парку полягає у повній заміні корпусу трамваю з використанням візка від старих трамваїв. При цьому для модернізації використовуються трамвайні вагони типу Т3, що виготовлені підприємством С̆KD TATRA (Чехословаччина) та експлуатується в КП «Одесміськелектротранс». У модернізованих вагонах 90\% деталей, включаючи кузов і дискову гальмівну систему, нові.

У середньому модернізація одного трамвайного вагону, враховуючи поточні ціни на базові види робіт з іï проведення за підрахунками авторів, становить близько 5,5 млн гривень, що майже у 3 рази менше витрат на придбання нового трамваю.

Технічні характеристики модернізованого вагону такі: обладнаний пандусом для заїзду пасажирів на інвалідних візках, візуальною інформаційною системою оповіщення маршруту слідування для пасажирів 3 порушеннями слухового апарату, а також звуковою інформаційною системою для оповіщення пасажирів 3 вадами зору; встановлено нові сучасні м'які сидіння та нове планування вагону.

Сьогодні виробничі потужності КП «Одесміськелектротранс» дозволяють виконувати роботи 3 модернізації одного трамвайного вагона на місяць. Таким чином, за рік підприємство своїми силами може оновити 12 трамвайних вагонів. Усього ж заміні підлягають 217 вагонів, 3 них негайної заміни потребують 55 вагонів, вік яких перевищуе 35 років.

Роботи 3 модернізації рухомого складу дадуть можливість зменшити експлуатаційні витрати підприємства на $15 \%-20 \%$, знизити рівень витрат електроенергії до $30 \%$, продовжити термін експлуатації трамвайних вагонів до 15 років.

Річний економічний ефект від введення в експлуатацію модернізованих трамвайних вагонів буде досягнуто за рахунок:

1) зменшення експлуатаційних витрат на усунення технічних несправностей, які мали місце на старому рухомому складі (витрати на матеріали та запасні частини на ремонти (малі та середні) зменшаться на $15 \%$ );

2) зменшення витрат на заробітну плату працівникам ремонтної служби підприємства (фактична частка трудових витрат, яка припадає на зарплату на проведення середніх ремонтів в загальній сумі зарплати ремонтних працівників сягає $20 \%$ );

3) зменшення споживання електричної енергії у середньому на $30 \%$.

Виконавши розрахунки, аналогічні тим, що представлені у таблиці 1, отримуємо річний економічний ефект від проведеної модернізації трамваїв у розмірі 582,25 тис. грн. Таким чином, для реалізації проекту з модернізації 12 трамваїв протягом 2017 рокуКП «Одесміськелектротранс» необхідно близько 66 млн грн, у порівнянні закупівля повністю нових 12 трамваїв обійдеться у 180 млн грн. Отже, проведення модернізації старих трамвайних вагонів $\epsilon$ оптимальним варіантом оновлення рухомого складу підприємства за умов відсутності коштів на закупівлю нових трамваїв.

У підсумку за рахунок успішної реалізації обох умовних проектів, а саме закупівлі 48 нових тролейбусів «Богдан Т70117» та проведення модернізації 12 трамваїв «Татра» матиме місце підвищення ефективності господарської діяльності підприємства за рахунок скорочення витрат на експлуатацію рухомого складу, як результат річна економія коштів КП «Одесміськелектротранс» складе 7,427 млн грн.

\section{Висновки i перспективи подальших} досліджень. Враховуючи вищевикладене, подолання кризового стану міського електричного транспорту та забезпечення населення якісними транспортними послугами можливе шляхом реалізації інноваційних проектів, спрямованих на техніко-технологічне переоснащення підприємств галузі, що, у свою 
чергу, вимагає виявлення та використання інвестиційних джерел. Вирішити проблему інноваційного оновлення основних засобів міського електротранспорту дозволить впровадження таких пріоритетних напрямів розвитку підприємств галузі як інноваційне оновлення технічної бази та модернізація існуючого рухомого складу, що призведе до підвищення якості транспортних послуг, поліпшення екологічної ситуації в місті, підвищення престижності, прибутковості та інвестиційної привабливості підприємств. Однак поряд 3 інноваційним розвитком електротранспортних підприємств необхідно враховувати можливості підвищення доходів підприємств за рахунок удосконалення тарифної політики та механізму стягування плати за пасажирські перевезення, враховуючи специфіку надання субсидій $з$ місцевого бюджету та перелік пільгових категорій населення, що потребує додаткових досліджень у даному питанні.

\section{ПЕРЕЛІК ВИКОРИСТАНИХ ДЖЕРЕЛ}

1. Амоша О. I. Свропейський досвід забезпечення ефективного функціонування підприємств міського пасажирського транспорту / О. І. Амоша, О. С. Філіппова // Економіка будівництва і міського господарства. 2010. - № 4. - C.179-189.

2. Філіппова О. С. Оцінювання проблем розвитку міського електротранспорту в Україні / О. С. Філіппова // Галицький економічний вісник. - 2012. - №1 (34). - С. 72-84.

3. Омельянович О. Р. Особливості та пріоритети стратегічного розвитку підприємств міського електротранспорту в сучасних кризових умовах в Україні / О. Р. Омельянович, Ю. І. Прима // Економіка та управління на транспорті. - 2016. - № 3. - С. 59-65.

4. Дивінець О. Л. Стратегічні пріоритети розвитку міських електротранспортних підприємств України / О.Л. Дивінець // Європейський вектор економічного розвитку. - 2015. - № 1 (18). - С. 74-83.

5. Чеканова Л. Г. Аналіз стану та перспектив розвитку міського наземного електричного транспорту / Л. Г. Чеканова, О. Ю. Палант, Т. Б. Кушнір // Научно-технический сборник. - 2010. - № 92. - С. $150-153$.

6. Об'єкти міського електротранспорту України станом на 01.01.2017 р. [Електронний ресурс] / Офіційний сайт корпорації підприємств міського електротранспорту України «Укрелектротранс» // Об'єкти міського електротранспорту. - Режим доступу: http://korpmet.org.ua/?page_id=67.

7. EBRD commits $€ 100$ million to improving public transport in Ukrainian municipalities [Електронний ресурс] // The European Bank for Reconstruction and Development. - Режим доступу: http://www.ebrd.com.

8. Гнедіна К. В. Джерела фінансування інноваційного оновлення міського електричного транспорту/ К. В. Гнедіна // Формування ринкових відносин в Україні. - 2008. - №12 (91). - С. 93-96.

9. Основні показники роботи підприємств міського електротранспору України за 9 місяців 2016 року [Електронний ресурс] / Офіційний сайт корпорації підприємств міського електротранспорту України «Укрелектротранс» // Аналітична інформація. - Режим доступу: http://korpmet.org.ua/?page_id=48.

10. Коммунальное предприятие «Одесгорэлектротранс» [Электронный ресурс] / Официальная страница коммунального предприятия «Одесгорэлектротранс». - Режим доступа: http://www.oget.od.ua.

11. Сапронов О. Р. Історія, стан і перспективи розвитку міського електротранспорту в Україні / О. Р. Сапронов // Освіта і управління. - 2007. - Т.10, №3/4. - С. 145-150.

12. Жаліло Я. А. Теорія та практика формування ефективної економічної стратегії держави : монографія / Я. А. Жаліло. - К.: Національний інститут стратегічних досліджень, 2009. - 336 с.

13. Финансирование с участием ЕБРР [Электронный ресурс] / Официальный сайт Европейского банка реконструкции и развития. - 2013. - Режим доступа: http://www.ebrd.com/downloads/research/factsheets/guider.pdf

\section{REFERENCES}

1. Amosha, O. I. \& Filippova, O. S. (2010). Yevropeiskyi dosvid zabezpechennia efektyvnoho funktsionuvannia pidpryiemstv miskoho pasazhyrskoho transport [European experience ensuring effective functioning of urban passenger transport]. Ekonomika budivnytstva i miskoho hospodarstva -Building and Municipal Economy, 4, pp. 179-189 [in Ukrainian].

2. Filippova, O. S. (2012). Otsiniuvannia problem rozvytku miskoho elektrotransportu v Ukraini [Estimation problems of public electric transport development in Ukraine]. Halytskyi ekonomichnyi visnyk - Galician Economic Journal, 1 (34), pp. 72-84 [in Ukrainian].

3. Omelianovych, O. R. \& Pryma, Yu. I. (2016). Osoblyvosti ta priorytety stratehichnoho rozvytku pidpryiemstv miskoho elektrotransportu $\mathrm{v}$ suchasnykh kryzovykh umovakh $\mathrm{v}$ Ukraini [Features and priorities of strategic development of municipal electric transport companies in the current crisis in Ukraine]. Ekonomika ta upravlinnia na transporti - Economy and Transport Management, 3, pp. 59-65 [in Ukrainian].

4. Dyvinets, O. L. (2015). Stratehichni priorytety rozvytku miskykh elektrotransportnykh pidpryiemstv Ukrainy [Strategic priorities of the development of urban electric transport enterprises of Ukraine]. Yevropeiskyi vektor ekonomichnoho rozvytku - European vector of economic development, 1(18), pp. 74-83 [in Ukrainian]. 
5. Chekanova, L. H.; Palant, O. Yu. \& Kushnir, T. B. (2010). Analiz stanu ta perspektyv rozvytku miskoho nazemnoho elektrychnoho transportu [Analysis of a condition and prospects of urban surface electric transport]. Nauchno-tekhnycheskyi sbornyk - Scientific and Technical collections, 92, pp.150-153 [in Ukrainian].

6. Obiekty miskoho elektrotransportu Ukrainy stanom na 01.01.2017 [Objects of Ukrainian urban electric transport as of 01.01.2017]. (2006). korpmet.org.ua. Retrieved from http://korpmet.org.ua/?page_id=67 [in Ukrainian].

7. EBRD commits $€ 100$ million to improving public transport in Ukrainian municipalities (n.d.). The European Bank for Reconstruction and Developmen. Retrieved from http://www.ebrd.com [in English].

8. Hnedina, K. V. (2008). Dzherela finansuvannia innovatsiinoho onovlennia miskoho elektrychnoho transport [Sources of financing innovative renewal of urban electric transport]. Formuvannia rynkovykh vidnosyn v Ukraini Formation of market relations in Ukraine, 12 (91), pp. 93-96 [in Ukrainian].

9. Osnovni pokaznyky roboty pidpryiemstv miskoho elektrotransporu Ukrainy za 9 misiatsiv 2016 roku [Main work indicators of Ukrainian urban electric transport enterprises during 9 months of 2016]. (2016). korpmet.org.ua. Retrieved from http://korpmet.org.ua/?page_id=48 [in Ukrainian].

10. Kommunalnoe predpriyatie «Odesgorelektrotrans [The Municipal Enterprise «Odesgorelektrotrans»]. Ofitsialnaya stranitsa kommunalnogo predpriyatiya «Odesgorelektrotrans» - Website of Municipal Enterprise «Odesgorelektrotrans». (n.d.). Retrieved from http://www.oget.od.ua [in Russian].

11. Sapronov, O. R. (2007). Istoriia, stan i perspektyvy rozvytku miskoho elektrotransportu v Ukraini [History and prospects of developing urban electric in Ukraine]. Osvita i upravlinnia - Education and Management, 10 (3/4), pp. $145-150$ [in Ukrainian].

12.Zhalilo, Ya. A. (2009). Teoriia ta praktyka formuvannia efektyvnoi ekonomichnoi stratehii derzhavy [Theory and practice of forming an effective economic strategy of the state]. Kyiv: Natsionalnyi instytut stratehichnykh doslidzhen [in Ukrainian].

13. Finansirovanie $\mathrm{s}$ uchastiem EBRR [Financing with the EBRD]. Ofitsialnyiy sayt Evropeyskogo banka rekonstruktsii i razvitiya - Official site of the European Bank for Reconstruction and Development. (2013). Retrieved from http://www.ebrd.com/downloads/research/factsheets/guider.pdf [in Russian].

Одержано 14.07.2017p. 